\title{
The relation between the CSR and the accounting information system data in Central and Eastern European (CEE) countries - the evidence of the Polish financial institutions
}

\author{
Justyna Fijałkowska a , Beata Zyznarska-Dworczak ${ }^{\text {b1 }}$ and \\ Przemysław Garsztka ${ }^{b}$ \\ ${ }^{\mathrm{a}}$ University of Social Sciences, \\ ${ }^{\mathrm{b}}$ Poznan University of Economics and Business
}

\begin{abstract}
Financial institutions play a fundamental role in determining the sustainability of economies, both in developed and developing countries. However, the worldwide financial crises made many financial institutions lost their credibility and CSR engagement has been perceived as a remedy. The aim of this paper is to analyze the interrelation between being socially responsible and tangible financial outcome of financial institutions in one of the CEE countries - Poland. Financial and market data of all the public companies from the financial sector in Poland 116 financial institutions. The analyzed period is 2012-2015 that gives 257 observations. The empirical results reveal that in case of financial institutions in Poland the slack resources are strongly related to CSR involvement, however being socially responsible is not reflected in the bottom line. Polish market and the public are reluctant in considering the CSR importance and the CSR engagement is not rewarded. This undermines the role of CSR commitment in financial institutions in CEECs. It may be assumed that CSR efforts in Poland are not focused properly, or they are not communicated effectively. On the basis of comparative analysis is
\end{abstract}

\footnotetext{
${ }^{1}$ Corresponding authors: Department of Accounting, Poznan University of Economics and Business; Al. Niepodległości 10, 61-875 Poznań; email adresses:

jfijalkowska@spoleczna.pl; b.zyznarska-dworczak@ue.poznan.pl; przemyslaw.garsztka@ue.poznan.pl;
} 
The relation between the CSR and the accounting information system data

in Central and Eastern European (CEE) countries - the evidence of the Polish financial institutions

presented there is a significant difference between CEE countries and other transitional countries in CSR implementation and communication. The findings are important in better understanding of the link between CSR engagement and its tangible outcomes in CEE countries. The conclusions may lead to the improved decision-making processes concerning CSR activities and their communication.

Keywords: CSR, financial performance, financial institutions, banks, Central and Eastern Europe, CEE, CEE countries.

JEL codes: M14, M40, M41, Q56

\section{Introduction}

Financial institutions play a fundamental role in determining the stability of financial markets, sustainability of modern economies and economic fortunes of nations. However, after the financial crises of 2008 many financial sector institutions have lost their credibility in the eyes of the consumers and investors. The economic crises originated from the financial markets and led to the lower trust in financial institutions, inferior investments and the recession (Fijałkowska \& Zyznarska, 2017). Social responsibility has been found to be a way for banks and other financial institutions to earn back their credibility (Cornett et al., 2014). Accounting information system is responsible for the collection, storage and processing of financial and accounting data that is used for internal management decision making, including nonfinancial transactions that directly affect the processing of financial transactions (Belfo \& Trigo, 2013: 537).

Reporting is probably the most important feature of accounting information system. As Huang and Watson (2015: 3) underline "there is a natural link between CSR and accounting because the accounting profession has a general responsibility for the measurement, disclosure, and assurance of information, including CSRrelated information". Rogošić and Čaljkušić (2015) indicate that "sustainability accounting is considered as a complement to the traditional financial accounting with a purpose to evaluate the environmental, social and governance performance of a company and to provide the report on this matter". Accounting information system should be therefore adjusted to the requirements of the public that becomes highly aware and sensitive regarding the accountability and disclosure of financial institutions.

The accountability and responsibility accounts may play an important role in the legitimizing of the financial institutions' activities and may be crucial in the 
reconstruction of the public trust. This issue becomes even more important nowadays, in the face of the new directive concerning the non-financial information disclosure by the biggest companies in the European Union (Directive 2014/95/EU), that is applicable also to the biggest financial institutions. As Yilmaz (2016: 96) underlines "The concepts of responsibility, accountability, transparency, equality and protection of interests, which represent the main components of corporate management, are impactful and important concepts not only in terms of social responsibility of accounting, but the whole information system of the business and specifically the accounting information system".

CSR value has attained extensive interest among practitioners and academics. Moreover, the substantial investments in the CRS makes the question concerning the link between CSR and Corporate Financial Performance continuously noteworthy. The interest of investors in company's non-financial performance has grown significantly over the past few years (Ernst \& Young, 2009). It is assumed that $67 \%$ of investors, while taking economic decisions, consider the non-financial information disclosed by companies, $89 \%$ of investors threats them as the most important source of information influencing their decision (ACCA, 2013: 50). Moreover, it is expected that CSR activities may have an influence on the companies' overall performance and financial results.

Although CSR is often regarded as a universal concept, it should be highlighted that its actual meaning changes over time and differs between regions due to varying socio-political and cultural circumstances (Moon, 2007). This is due to the fact that the economic conditions, cultural inheritance, political grounds and government decisions influence the expectations of the users in general and the stakeholders' ones in particular, regarding the extent and the domains of the CSR. "While CSR has a particularly strong resonance in parts of Western Europe, it took root slowly in Central and Eastern Europe" (Feltham, 2016: 1).

According to the research conducted by Centrum CSR (2009:66) the recognition and level of implementation of principles of corporate social responsibility was "most likely still low among corporations in CEE region (there may be a case of non-communicated CSR)". However, as it is underlined in the research mentioned "there is great potential for cooperation between business, civil society groups, trade unions and the authorities, as well as academics, in the field of social policy, including outward foreign investment (both incoming and outgoing) in every country in Central and Eastern Europe". Although CSR policies would be crucial to gaining comparative advantage for this region, there are many different obstacles of CSR implementation and communication, like: negative image of business, dysfunctional legal background, corruption, weakness of the III sector, difficult economic situation of many companies, the lack of an ethics and ethical standards, and difficult situation on the job market (Lewicka-Strzalecka, 2006: 440). 
Furthermore, some studies prove also that less developed and more turbulent business regulatory and legal systems in CEE countries lead to the situation that financial considerations take higher precedence over social and environmental responsibility activities of organizations (Filatotchev et al. 2000, Vynoslavska et al. 2005). The research of Inglehart and Welzel (2005) indicates that in richer and more stable countries such as those in Western Europe, individuals are more likely to have adapted to their current material level with the result that they focus more on such issues as social welfare and environmental sustainability. Moreover Steurer and Martinuzzi (2012), prove that Western European countries, particularly Anglo-Saxon and Scandinavian, governments are significantly more active in promoting CSR than governments in CEE countries and they conclude that public policies on CSR reinforce rather than offset the European "CSR gap".

Market participants in Western European countries have significantly different perspectives on the importance of corporate responsibilities than those in Central and East European countries". Furrer et al. (2010) investigate corporate responsibilities practices across different societies and different generations within those societies and they indicate that in Central and East Europe, there is less tangible evidence that CSR has been high on the business agenda. The accession of ten Central and East Europe countries to the EU in 2004 and two more in 2007 has raised significant concerns regarding corporate responsibility priorities in these transitional economies (Vaughan-Whitehead, 2003). Csafor (2008:115) notices "Corporate Social Responsibility (CSR) has only a short past in the former socialist countries of Eastern Europe, but growing demand for CSR can be felt in these states as well". CSR research in accounting is definitely more visible within the international academic community than 40 years ago, but it still seems to be a research niche in countries that do not have a long CSR tradition and practice, such as the CEE countries (Albu et al. 2016: 202). While the international CSR research grew significantly over the last decade, there is a shortage of research investigating the nature and extent of CSR in $\mathrm{CEE}^{\mathrm{i}}$ countries, as compared to more developed countries (Albu et al., 2016: 203).

The primary objective of this paper is to empirically analyze if there is an impact of being socially responsible on the tangible financial consequences of financial institutions in one of the CEE countries, namely in Poland. The empirical analysis aims also in analysis if the financial resources make companies get involved in CSR. The paper is structured as follows: the next section concerns the social responsibility and sustainability in financial institutions, the third sections focuses on the relation between CSR and corporate financial performance. This part is based on the CSR / CFP relation analysis based on assumptions concerning the social impact hypothesis, available funding hypothesis (slack resources hypothesis), positive synergy hypothesis, negative synergy hypothesis, trade-off hypothesis and managerial opportunism hypothesis. The fourth section contains the 
results of empirical analysis and is followed by concluding remarks and comparison with the results of other studies concerning different CEE countries. The findings of this study are important for the financial institution sector in order to better understand the link between their CSR investment and tangible outcomes that may lead to the improved decision-taking processes. In the paper the normative approach to accounting and management is adopted.

\section{Corporate social responsibility and financial institutions}

The financial services sector is viewed as a central pillar of modern capitalist economies (Merton,1995; Levine, 1997; 2005). Financial institutions have an impact not only on financial and economic system, but on a wider community as well. Their socially responsible practices in particular may have important social implications, hat is even more emphasized within bank-centric financial systems, typical of CEE countries (Hernaus \& Storjanovic, 2015). The services executed by banks and other financial institutions are characterized by information asymmetry and uncertainty which makes trust a necessary condition for doing business (Beck, 2006; Schanz, 2006). Trust is a central strategic issue for financial services firms (Llewellyn, 2005; Olsen, 2008) and is strictly related to the reputation, that is a multi-faceted concept embracing many components. Rossier (2003) highlights a number of reasons why bankers, in particular, have to consider issues of reputation. The bankers and other participants of financial sector trade money which represents other people's security and well-being. They are also involved in a profession that has been held in contempt, since medieval times because of usury (Fijałkowska, 2012: 141).

Today the credibility, accountability and reputation of financial sector is in its foundations and determines the stability of financial markets (Gaultier-Galliard \& Louisot, 2006). Decker and Sale (2009: 137) notice that "reputation is built on the trust that is established with all stakeholders and as an intangible asset it directly affects the value of financial services firms and is crucial to their sustainability and to the economic sustainability of society". As Stansfield (2006: 470) states reputation in financial institutions concerns "financial performance and strength, client trust and confidence, client service, corporate social responsibility, corporate governance practices, corporate ethics, corporate disclosure practices, as well as relations with regulatory authorities and compliance in a broad sense". Decker and Sale (2009: 137) add that "key CSR principles such as accountability and transparency are at the heart of regulatory efforts to ensure banks and bankers operate with trust". They continue underlining that "reputation is built on the trust that is established with all stakeholders and as an intangible asset it directly affects the value of financial services firms and is crucial to their sustainability and to the economic sustainability of society". 
The relation between the CSR and the accounting information system data

in Central and Eastern European (CEE) countries - the evidence of the Polish financial institutions

UNEP (2004) indicates "The financial sector can play a critical role in the transformation to a more sustainable environment. As financial intermediaries in an economy, financial institutions can contribute to mitigating environmental problems, while at the same time taking advantage of the opportunities that sustainability offers to the finance sector". Bossone (2000) and Olson (2006) argue that trust and confidence in banking will continue to be important and vital to society's financial well-being. The concept of Corporate Social Responsibility (CSR) is closely related to trust and reputation and therefore it is an increasingly important issue in the international banking industry (Scholtens, 2009) and in the financial sector as a whole. According to Minor (2009), when managers are asked why they engage in CSR, they claim it is to secure a better brand and reputation. However, as Fombrun (1996: 53), suggest "the activities that generate CSR do not directly impact the company's financial performance, but instead affect the bottom line via its stock of 'reputation capital' -the financial value of its intangible assets".

Financial institutions face various pressure to shift to a new business framework that requires social responsibility approach to their activates. Corporate social responsibility has been a subject of great interest for more than 30 years among scholars from multiple management perspectives (Wang et al., 2016: 1084). CSR can be defined as "the process of communicating the social and environmental effects of organizations' economic actions to particular interest groups within society and to society at large" (Gray et al., 1987: ix). The concept of CSR is related with sustainability. The relation between CSR an sustainability is underlined in the definition published by International Organization for Standardization's, stating that "Social responsibility is the responsibility of an organisation for the impacts of its decisions and activities on society and the environment, through transparent and ethical behaviour that contributes to sustainable development (..)" (ISO 26000).

CSR is widely understood as an obligation of entrepreneurs to contribute to the sustainable socio-economic development (IBLF 2003). Sustainable business models "follow a comprehensive sustainability logic that integrates economic, ecological, and social considerations with regards to present and future generations" (Schneider, 2015: 525) - while disclosing information concerning CSR and sustainability financial institutions often use those two related concepts interchangeably. As Jurek (2016: 68) underlines "CSR in financial institutions should not be seen only in terms of interactions between different stakeholders (Shareholders, investors, depositors, borrowers, regulators) and financial institutions" in the fields of economic, legal, ethical and philanthropic responsibility, but "also in the context of their distinctive function of financial intermediaries" The figure below presents the main internal and external groups of financial institutions' stakeholders (as the most important players in the whole financial institutions' sector) towards which they should be responsible. 


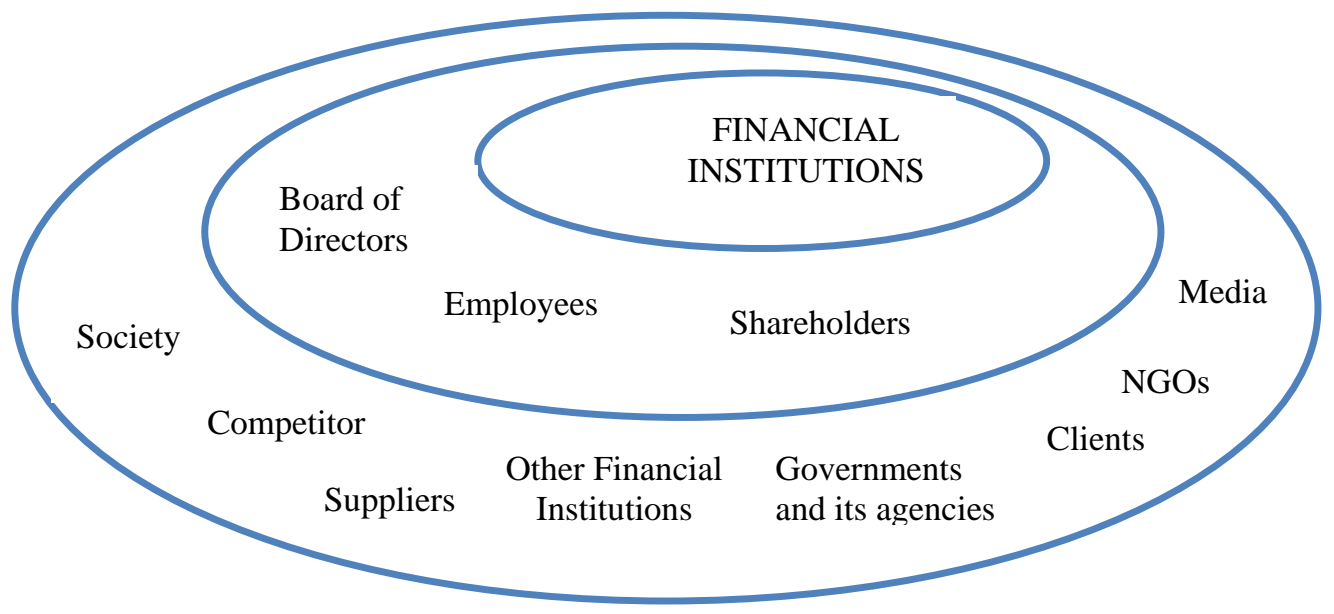

Figure 1. Internal and External stakeholders of financial institutions

As it was underlined during the World Economic Forum in 2012 "finance plays a critical role for society at large, serving individuals, families, businesses, governments and civic institutions. The financial sector performs indispensable functions such as enabling saving and investment, providing protection from risks and supporting the creation of new jobs and enterprises. It is critical that the sector operates to provide these functions for society in a stable, sustainable way". The dimensions of CSR in financial institutions, based on the Carrols' (1991) framework are presented in the Table 1.

\section{Table 1. Dimensions of CSR in financial institutions}

\begin{tabular}{ll}
\hline \multicolumn{1}{c}{$\begin{array}{c}\text { Dimension of } \\
\text { responsibility }\end{array}$} & Description \\
\hline Economic & $\begin{array}{l}\text { Financial institutions should improve the wealth of the owners, create } \\
\text { new opportunities for risk management and offer the efficient transfer } \\
\text { of funds } \\
\text { Legal responsibility is largely determined by legal regulations } \\
\text { concerning for example the requirement of maintaining confidence, } \\
\text { the limitations of risk taking, arbitrate relationship between the } \\
\text { financial sector and society. } \\
\text { Regulations constitute a pillar of financial institutions responsibility } \\
\text { and are supposed to rebuild trust and prevent from similar to 2007 } \\
\text { and } 2008 \text { crises. } \\
\text { Ethical codes should be implemented in financial institutions. } \\
\text { Honesty and good faith, professional integrity, transparency and } \\
\text { accountability are ethical values crucial financial institutions, to } \\
\text { achieve by: } \\
\bullet \quad \text { Integrity -to generate trust that is vital for a financial system }\end{array}$ \\
\hline
\end{tabular}


The relation between the CSR and the accounting information system data

in Central and Eastern European (CEE) countries - the evidence of the Polish financial institutions

\begin{tabular}{cc}
\hline $\begin{array}{c}\text { Dimension of } \\
\text { responsibility }\end{array}$ & \multicolumn{1}{c}{ Description } \\
\hline to flourish; \\
Responsibility - the responsibility to act fairly, i.e. they have \\
the responsibility not to exclude certain groups.
\end{tabular}

Financial sector due to the crisis in 2007 and 2008 suffers the loss of trust and credibility. The study of Barjaktarović et al. (2013) proved negative effects of the economic crisis on the banking sectors of the selected CEE countries. The financial and economic crisis strongly influenced the entire world, however, Central and Eastern Europe (CEE) was particularly severely affected. Živković and Aktan (2009) stress that the emerging countries are faced with lower liquidity level, more frequent internal and external shocks, as well as a higher degree of insider trading causes. These countries are more vulnerable to the factors that generally lead to banking turbulences and that amplify their impact such as banks and private agents exposure to currency and maturity mismatch, disruption in international capital markets, banks panic (Furceri \& Zdzienicka, 2010). However, it is worth mentioning that in 2009, immediately after the crisis, while most of the EU was wallowing in a recession, the GDP of Poland actually grew by $1.7 \%$. (Eurostat) This is compared to its European neighbours (the EU27) whose aggregate loss of GDP fell to $4.2 \%$ (Eurostat). Before the crises banks were generally not extensively involved in CSR and in its disclosure (Novokmet \& Rogosic, 2016: 115). Vigano and Nicolai (2006) indicate that European bankers have been slow in considering issues of sustainability.

Moreover, the financial sector was traditionally viewed as not having much negative environmental impact, relatively non-polluting. The main impact on the society was always concerned mainly with its significant size. After the financial crisis however, the situation changed; financial sector reputation suffered from the consumers' perceptions of the sectors' crucial role in the crisis. Therefore, since then CSR activeness and CSR reporting in financial institutions have become one of the main tools of rebuilding trust (Novokmet \& Rogosić, 2016: 115). It was always more important for financial institutions to focus on the "sustainable finance" that is defined by Strandberg (2005) as the provision of financial capital and risk management products and services in ways that promote or do not harm economic prosperity, ecological and community wellbeing. The imperative for the financial sector became also the proper communication on the responsible attitude to the business running. Nowadays, one of the most important ways to express the 
social responsibility of financial institutions is the publication of CSR / sustainable reports and website disclosure. The question arises if the involvement and communication on CSR brings the concrete tangible results that can be expressed by improved financial results. The empirical analysis is the subject of the research that is included in part 4 of this article.

\section{Relation between corporate social responsibility (CSR) and corporate financial performance (CFP) - literature review}

There are three major theories which suggest that companies should be sustainable and should incorporate corporate sustainability in their core strategic goals, namely legitimacy theory, stakeholder theory and agency theory (Zyznarska-Dworczak, 2016: 308). In the literature these theories are often contrasted with Friedman's (1970) well-known criticism of a firm's corporate social responsibility initiatives. These theories primarily suggest positive relationship between corporate sustainability and company performance (Aggarwal, 2013: 63). Together with slack resources theory they give foundations to our analysis.

The relationship between CSR and corporate financial performance (CFP) has been a subject of numerous scientific studies since 50 years (Friedman, 1970; Preston \& O'Bannon, 1997; Waddock \& Graves, 1997; McWilliams \& Siegel, 2001; Smith, 2002; Orlitzky et al., 2003; Allouche \& Laroche, 2005; Margolis et al., 2007; Aggarwal, 2013; Kleine et al., 2013; Wang et al., 2016). The results do not lead to uniform conclusions, moreover they are inconclusive and conflicting. Some of these contradictory results stem from conceptual, operationalization, and methodical differences in the definitions and application of both social and financial performance (Griffin \& Mahon, 1997: 7).

There is a group of researchers that empirically confirm that the relation between CSR and CFP is stronger for firms from advanced economies than for firms from developing economies. This relationship is also significantly different between industries, sectors and institutions (Wang et al., 2016; Ioannou \& Serafeim 2010). Furthermore, the researchers affirm that the heterogeneity of the CSR and CFP relationship may result from the measurement strategies of the two key constructs of CSR and CFP (Wang et al., 2016: 24). There is no common way of the CSR measurement. One approach to judge a company as a socially responsibility is its inclusion into one of the CSR indexes, e.g. Indexes of Corporate Governance (CG), Indexes of Corporate Social Responsibility (CSR), index of Corporate Social Performance (CSP), GRI-based Disclosure Index Scores, Respect Index. Another way to define that a company is socially responsible is the publication of 
The relation between the CSR and the accounting information system data

in Central and Eastern European (CEE) countries - the evidence of the Polish financial institutions

CSR/sustainability reports. These approaches of CSR measurement are combined to the various types of CFP indicators that may be generally divided into two groups:

1. Accounting-based measures - like ROE (Return of Equity), ROA (Return of Assets), ROS (Return of Sales), Debt/Equity, Current Ratio, Debt/Assets, EBIT/Interest Expense, Quick Ratio, Total Assets, EPS, and

2. Market-based measures - like Alpha, Beta, Price/Earnings, CAR (Capital Adequacy Ratio), Total Return, Mean Abnormal Returns, Risk Adjusted Return, Stock Price, Market to Book Value.

Combination of these different approaches to CSR and SFP results in multitude of diverse applications and results of empirical analysis. Additionally, the interrelation between CSR and CFP may be analyzed twofold :

1. the direction of the CSR-CFP relation,

2. the causality of the CSR-CFP relation:

(a) prior CSR related to subsequent CFP;

(b) prior CFP related to subsequent CSR;

(c) concurrent and across relationship between CSR vs CFP.

The direction of the relationship may indicate positive, negative, mixed or neutral linkages between CSR and financial performance. Separately, it is possible that changes in CSR influence financial performance, or the opposite, that change in financial performance influence CSR (Waddock \& Graves 1997: 305), or there is a synergistic relationship between the two, either positive or negative. By combining these two dimensions of variation Preston and O'Bannon (1997) yield the six possible causal and directional hypotheses (Preston \& Bannon, 1997: 419-424):

1. with positive direction: social impact hypothesis, available funding hypothesis (slack resources hypothesis) and positive synergy hypothesis;

2. with negative direction: negative synergy hypothesis, trade-off hypothesis and managerial opportunism hypothesis.

Positive impact of social performance on financial performance explains social impact hypothesis, which is a "social impact" version of the stakeholder theory. This hypothesis assumes that CSR enhances the satisfaction of various stakeholders - and consequently the firm's external reputation - leading to better financial performance, in particular by increasing the efficiency of their organization's adaptation to external demands "by addressing and balancing the claims of multiple stakeholders" (Orlitsky et al., 2003: 405).

Social impact hypothesis assumes that CSR increases managerial competencies, contributes to organizational knowledge about an entity's market, social, political, technological, and other environments, and thus enhances organizational efficiency (Orlitsky et al., 2003:407. All these "good" effects of CSR are labeled by Waddock 
and Graves (1997) under "good management theory". Other scholars (McGuire et al., 1988; Waddock \& Graves, 1997; Orlitzky et al., 2003; Seifert et al., 2004; Daniel et al., 2004, Margolis et al., 2007; Albertini, 2012) suggest that CSR and CFP are positively associated, "but that the causal relationship is from financial to social performance” (Preston \& O'Bannon, 1997: 423). This slack resources hypothesis means that better financial results potentially effect the availability of slack (financial and other) resources that support companies in investing in social performance activities, such as employee and community relations, or environmental protection (Waddock \& Graves 1997: 312). In this theory CSR is treated as an outcome of better financial performance and not a cause of it. The positive synergy hypothesis supposes that higher levels of CSR lead to an improvement of CFP, which offers the possibility of reinvestment in socially responsible actions (Allouche \& Laroche, 2005). There is a kind of "virtuous circle" formed by a simultaneous and interactive positive relation between CSR and CFP (Waddock \& Graves, 1997: 306).

However, there is also a negative synergy hypothesis that indicates a "vicious circle"; higher levels of CSR may lead to decreased CFP. Therefore, synergy hypothesis assumes that social and financial performance are synergetic, but whether positive or negative it should be detected based on the available statistical data (Preston \& Bannon, 1997: 424).

Negative social-financial performance relationships can be predicted by other 2 hypothesis: trade-off hypothesis and the managerial opportunism hypothesis. The trade-off hypothesis indicates, in accordance with Friedman`s attitude (1970) and other neoclassical economists' arguments, that "a firm's higher levels of social performance may lower its financial performance as compared to competitors" (Preston and O'Bannon, 1997: 421). "Because social action will have a price for the firm it also entails a competitive disadvantage" (Smith, 2002: 232) to other firms that are less socially active. The trade-off hypothesis claims that social accomplishments involve higher costs for an entity, for example capital expenditures on special equipment, machinery and real estate devoted to CSR, cost materials and services by purchase of inputs from suppliers who are socially responsible, higher wages and benefits as well as additional workers to enhance policies social performance (McWilliams \& Siegel 2001: 123). The costs, according to this argument, fall directly to the bottom line, reducing profits and thus shareholder wealth (Waddock \& Graves 1997: 310).

The managerial opportunism hypothesis indicates negative social-financial performance relationships stating: higher levels of financial performance lead to lower levels of social performance and in the opposite direction. While gaining better financial performance, the management may attempt to cash in by reducing social expenditure in order to increase their own short-term private gains. Inversely, with worse financial performance managers may attempt to offset and 
The relation between the CSR and the accounting information system data

in Central and Eastern European (CEE) countries - the evidence of the Polish financial institutions

justify their disappointing results by engaging in conspicuous social programs (Preston \& O’Bannon, 1997: 423).

Some theorists (Griffin \& Mahon, 1997; McWilliams \& Siegel 2001) have a generally negative attitude to the CSR and CFP analysis; they ponder that the link between CSR and CFP disappears when more accurate variables are introduced into econometric models, such as research and development intensity (Allouche \& Laroche, 2005). They argue also that there are so many intervening variables between CSR and CFP that there should be no reason to expect any relationship at all. Additionally, the measurement problems are still so wide that it alone can mask any real linkage that could exist (Waddock \& Graves, 1997: 310).

These theoretical assumptions concerning CSR and CFP relationship are summarized, through the literature review covering the period of 1963-2013 in the Table 2. They focus in two perspectives regarding CSR / CFP relation: its direction and its causality. The analysis of literature review presented in Table 2 indicates that the most popular causality regards social impact hypothesis. Most of analyzed results (Margolis \& Walsh, 2001; Peloza, 2009; Aggarwal, 2013; Clark et al., 2015; Kochalski, 2016) indicate the positive impact of CSR on corporate financial performance (CSR as dependent variable). The strength of this relation varies from $44 \%$ to $85 \%$. Furthermore, some of the researchers (Margolis \& Walsh, 2001; Orlitzky et al., 2003; Margolis et al., 2007; Albertini, 2012) indicate an inverse existing positive impact, in which the financial results determine the results of the CSR activities. This finding, in turn, confirms the assumption of slack resources hypothesis. Margolis and Walsh (2001) indicate that 53\% of the empirical research reviewed confirms a positive impact of good financial performance on CSR activities, while $24 \%$ shows no relation, $19 \%$ mixed and $5 \%$ negative relation. This kind of causality of CSP and CFP researched is often the subject of integrative, quantitative meta-analyses with a methodologically more rigorous review in many substantive areas of the bidirectional relationship between CSR and CFP (Orlitzky et al., 2003; Daniel et al., 2004; Allouche \& Laroche, 2005; Margolis et al., 2007; Wang et al., 2016). Meta-analysis however concentrates on the strength but not on the direction of the relation. 
Table 2. The results of studies of the empirical relationship between CSP and CSR presented in the literature

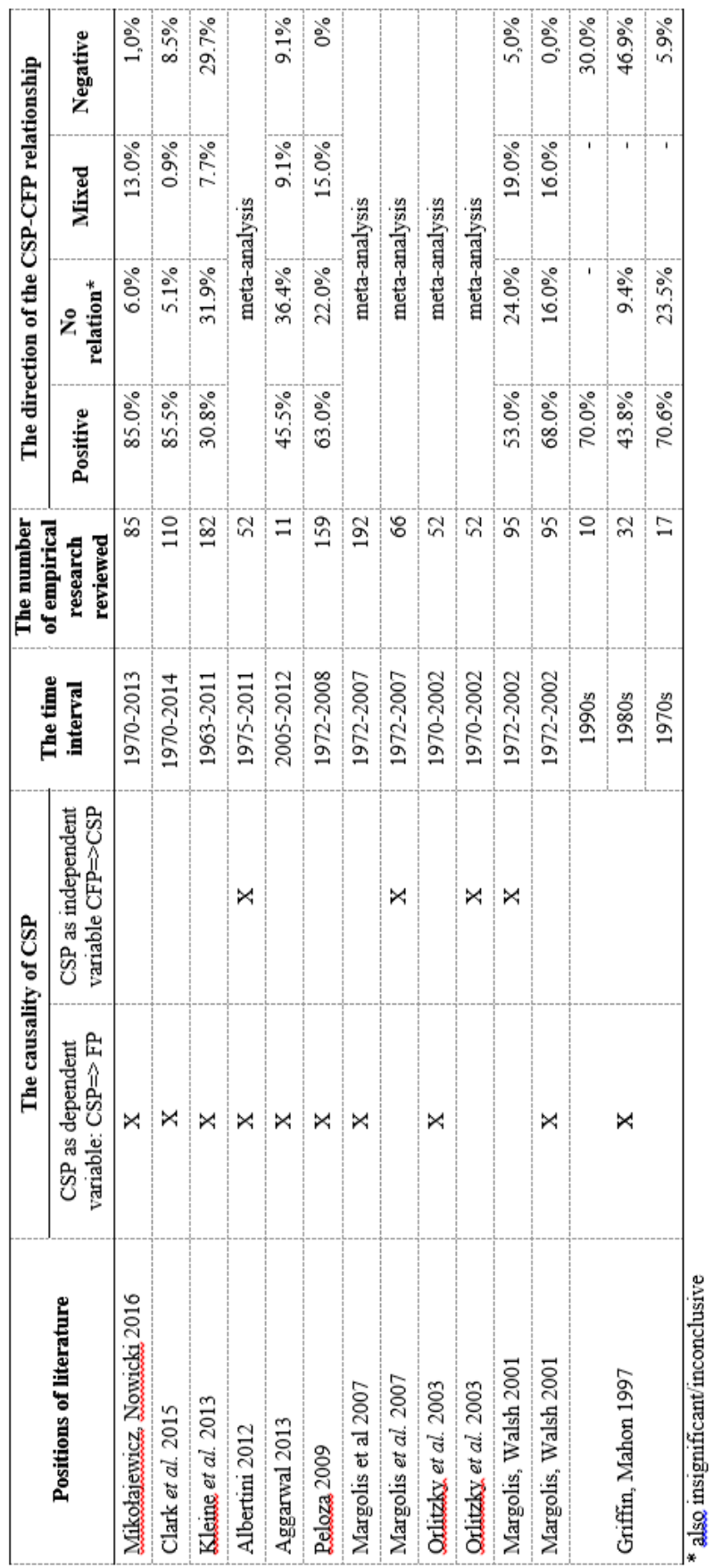


The relation between the CSR and the accounting information system data

in Central and Eastern European (CEE) countries - the evidence of the Polish financial institutions

The negative relation, confirming the trade-off hypothesis, was observed only in one direction: negative impact of CSR on the CFP. According to the analyze presented in Table 2 most of the tested research indicates the ratio of CSR-CFP influence below $10 \%$. The exception - with the much strongest influence - was a research conducted by Griffin and Mahon (1997). The researchers stated that in the 1980s almost $47 \%$ of tested literature position was a study that indicated the negative impact of CSR on the CFP and in the 1990s - 30\%. One more study (Kleine et al., 2013) has also shown such a high level of negative ratio $(29,7 \%)$.

We can conclude that in the period from 1972 to 2001, round-about ninety-five empirical evidences have been provided by Margolis and Walsh (2001) and Orlitzky et al. (2003) regarding CSR and financial performance. Many academics tried to analyze the relation between CSR and CFP. The results are not coherent neither conclusive. The literature review confirms the conclusions of Griffin and Mahon stated almost two decades ago; they underlined that "although numerous researches have explored the empirical relationship between SCP and CFP, no definitive consensus exists. The results have often been contradictory, even within a given analysis" (Griffin \& Mahon, 1997: 6).

Comparing the results with the findings of the study relating the transition countries we can also see the heterogeneity of the CSR and CFP relationship. According to the research conducted by Djalilov (2015: 20) CSR activities may improve the financial performance of the banks of the transition countries in both, stable (2002-2005) and turbulent (2008-2012) periods. However, the researchers have found that the impact of Return of Assets and Return on Equity on CSR is negative in both periods, while they have found positive impact of CSR on Return on Assets as well as Return on Equity. To the other conclusions have come Asatryan R. \& Březinová O. They found that there is a significant positive relationship between CSR initiatives and financial performance measures in the selected companies in Central and Eastern Europe, it means they found a positive relationship between Community Performance (CP), Environment Management System (EMS) and Employee Relations (ER) and the financial performance in terms of the ROE and ROA. Unfortunately, there is a lack of research relating the CSR-CFP in CEE countries, allowing for detailed and comprehensive analysis of this relationship.

Both in developed and developing countries there is still diversify and lack of an uniform understanding of CSR-CFP relations, which points to the need for the research that would order and synthetize the results as well as conclude on the CSR-CFP direction importance, its strength and dependence on the industry and size factor. There is also a need of the cohesive understanding of the influence of the CSR on the economic development in the micro and macro scale. 
The interest in CSR among practitioners as well as academics is still growing and as it plays a distinctive role within the financial sector institutions the following analysis will focus on this sector.

\section{Relation between corporate social responsibility (CSR) and corporate financial performance (CFP) - empirical research}

\subsection{Sample}

The financial data has been obtained from audited consolidated financial statements derived from EMIS database. To the great extent the accounting-based measures have been used because the audited accounting data is likely to be authentic and credible and is not influenced by market perceptions or speculations, and is thus considered less noisy in comparison to market based indicators like stock returns, share prices, etc. (Lopez et al., 2007). Market value was applied only as a control variable for size of companies. The data used to verify the hypotheses concerns listed companies which have the status of financial institution. Financial institutions in Poland are defined in the Code of Commercial Companies (Art. 4. § 1. 7) and comprise banks, investment companies, investment funds and trust funds, insurances, reinsurances, trusts, company pensions, retirement funds or brokerage houses, established in the Polish Republic or in a country belonging to the OECD.

The research embraced all the companies from the financial sector quoted on the Warsaw Stock Exchange in Poland. The analyzed period is 2012-2015. The collected data made it possible to calculate the change in earnings year on year. Then, the values obtained for each company separately for three consecutive years were treated as separate observations. In this way, the resulting study sample consisted of 298 observations. After removal of the observations for which there were missing data, calculations were performed on a sample of 257 observations.

\subsection{Variables}

\section{CSR variable}

CSR is difficult to measure. One of the approaches defines a socially responsible company as the one incorporated into one of the CSR indexes. The growth in the demand for ratings of CSR has resulted in a marked increase in the number of initiatives supplying CSR ratings to investors and customers (Marquez \& Fombrun, 2005: 304). The examples are KLD index, The FTSE 4 Good, Dow Jones S.UI. Stoxx, Domini 400 and Respect Index (RI) introduced by Warsaw Stock Exchange. In many empirical works the definition of being socially responsible is likened to 
The relation between the CSR and the accounting information system data

in Central and Eastern European (CEE) countries - the evidence

of the Polish financial institutions

one of these indices memberships. Another approach defines socially responsible company as the one that communicates its CSR engagement disclosing $\mathrm{CSR} /$ sustainable report. In this study both approaches were applied and analyzed.

\section{Financial Performance Measures variable}

In this study the following measures of financial performance were considered and analyzed: book value, market value, ROA and ROE.

\section{Control Variables}

The control variable used in this research was the size of the company, based on the assumption that larger firms are likely to have higher profitability as they have greater resources for investing in profitable ventures. Other control variables used in this study are long-term debt to assets ratio as a proxy for risk, and - for the purpose of verifying hypothesis $\mathrm{H} 1$ - the dummy variable indicating companies incorporated into PL-WIG-BANKI index for banks. We introduce this variable assuming that banks are financial institutions subject to more stringent reporting requirements and generally better managed than other financial institutions.

\subsection{Research model}

The first model intends to examine the impact of the overall sustainability rating of the financial institution (independent variable - CSR) and CSR reporting on its financial performance (dependent variables - CFP).

H1: Corporate social performance and financial performance are related (positively or negatively) across the financial sector institutions

This research hypothesis is based on two other hypotheses:

1. social impact hypothesis ( $\uparrow \mathrm{CSR} \Rightarrow \boldsymbol{\uparrow} \mathrm{CFP}$ )

2. trade-off hypothesis ( $\uparrow \mathrm{CSR}=>\downarrow$ CFP)

To verify the research hypothesis about the impact of the publication of the CSR report and the impact of the fact that the company is listed in a RESPECT Index (RI) on the change of its financial result in the following reporting year we used an econometric model:

$$
C F P_{t}=\alpha+\theta \cdot C S P_{t-1}+\sum_{i=1}^{I} \beta_{i} \cdot X_{i, t-1}+\varepsilon_{t}
$$

where $C F P_{t}$ means the change of financial performance at time $t$ (or financial performance where it is justified), $X_{i, t}$ is control variable at the same time $t$ and $C S P_{t}$ (corporate social performance) is dummy variable indicating fact of publication the CSR report or the fact that the company is listed in $R I$. 
Before we estimated model (1) we check if is there any correlation between $C S R_{t}$ (or $R I_{t}$ ) and financial variables. We used standard Spearman's rank correlation coefficient. Second test was to show whether the average financial results differ between companies with different $C S R(R I)$. We used Two-way Factorial ANOVA (analysis of variance).

The second model intends to examine the impact of financial results on the probability of publishing a CSR report and on the probability incorporating the company into RI.

H2: Financial results of financial institution impact (positively or negatively) the probability of its CSR reporting and the probability of incorporating the company into Respect Index

This hypothesis concerns two other hypothesis that may be found in the literature:

1. available funding hypothesis (slack resources hypothesis) $(\uparrow \mathrm{CFP}=>\uparrow \mathrm{CSR}$ )

2. managerial opportunism hypothesis ( $\uparrow \mathrm{CFP}=>\downarrow \mathrm{CSR})$,

In order to verify the second research hypothesis we estimated binary logistic regression:

$$
\begin{aligned}
& \pi_{j}=\operatorname{Pr}\left(C S P_{j, t}=1 \mid X_{i}=x_{i}\right) \\
& \log \left(\frac{\pi_{j}}{1-\pi_{j}}\right)=\alpha+\theta_{1} \cdot F P_{j, t-1}+\theta_{2} \cdot W I G_{j, t-1}+\sum_{i=1}^{I} \beta_{i} \cdot X_{i, t-1}+\varepsilon
\end{aligned}
$$

where $C S P j_{, t}$ is response variable, equal 1 when company $j$ published CSR report, or when company $j$ was incorporated into RI, $W I G_{j, t}$ is dummy variable indicated companies incorporated into PL-WIG-BANKI index for banks and $X_{i, t}$ are the control variables.

\subsection{Results of the analysis}

The first analysis aimed to test the hypothesis about the impact of the CSR report publication and the impact of the company's presence on the RESPECT Index (RI) on the change in the financial results of the following reporting year.

Spearman's correlation coefficients results are presented in Table 3. Statistically significant correlation occurs between CSR variables (CSR reports / RI) and book value change, as well as between CSR variables and market value (capitalization). However, correlation coefficients do not show a clear relationship between these variables. 
The relation between the CSR and the accounting information system data in Central and Eastern European (CEE) countries - the evidence of the Polish financial institutions

Table 3. Spearman correlation between financial data and CSR \& RI from previous year

\begin{tabular}{lllll}
\hline Spearman & $\Delta R O A_{t}$ & $\Delta R O E_{t}$ & ${\text { (Market value })_{t}}$ & $\begin{array}{l}\Delta \text { (Net profit) } \\
t\end{array}$ \\
\hline $\mathrm{CSR}_{\mathrm{t}-1}$ & -0.0589 & -0.0496 & $0.367565 * * *$ & 0.06459 \\
$\mathrm{RI}_{\mathrm{t}-1}$ & -0.0693 & -0.0989 & $0.43707 * * *$ & 0.01864 \\
& & \\
\hline $\mathrm{p}<0.1 * * \mathrm{p}<0.05 * * * \mathrm{p}<0.01 * * * * \mathrm{p}<0.001$
\end{tabular}

The next stage of verification of the first research hypothesis is to check whether there are significant differences in the average value of the variables reflecting financial results for the following year between the companies that have published the CSR report and those that did not published it. In order to analyze it we use Two-way Factorial ANOVA.

The ANOVA test showed that the hypotheses about equality of vectors concerning mean value of changes in financial results between groups cannot be rejected (stat. $\mathrm{F}=1,5926 ; \mathrm{p}=0,1627)$. To verify whether the individual values are significantly different, one-dimensional results (Table 4) are checked.

Table 4. Two-way Factorial ANOVA of financial data for CSR (1 - publication of the report ; 0 - otherwise) and RI (1 - company in RESPECT Index; 0 otherwise) as a treatment. Depend variables are change of financial data.

\begin{tabular}{lllll}
\hline & $\Delta R O A_{t}$ & $\Delta R O E_{t}$ & ${\text { (Market value })_{t}}$ & $\begin{array}{l}\Delta \text { (Net profit) } \\
t\end{array}$ \\
\hline Source & $\mathrm{F}-$ stat & $\mathrm{F}-\mathrm{stat}$ & $\mathrm{F}-\mathrm{stat}$ & $\mathrm{F}-$ stat \\
$\mathrm{CSR}_{\mathrm{t}-1}$ & 0.0348 & 0.2898 & 2.3429 & 1.8174 \\
$\mathrm{RI}_{\mathrm{t}-1}$ & 0.0331 & 0.0086 & $72.115 * * * *$ & 0.0207 \\
$\mathrm{CSR}_{\mathrm{t}-1} * \mathrm{RI}_{\mathrm{t}-}$ & 0.0264 & 0.5536 & 0.0639 & 1.3054 \\
1 & & & & \\
\hline \multicolumn{5}{l}{$\mathrm{p}<0.1 * * \mathrm{p}<0.05 * * * \mathrm{p}<0.01 * * * * \mathrm{p}<0.001$}
\end{tabular}

The only statistically significant difference regarded the changes in the book value. A similar test was used for companies that were part of the RESPECT Index compared to other companies. For the vector of average change of the financial result between the analyzed groups, the hypothesis should be rejected (stat $\mathrm{F}=$ 16,$2967 ; \mathrm{p}<0.0001$ ). In this case, for a one-dimensional result (Table 4), the statistically significant difference occurs between the average market valuation for RI companies and the rest. 
In case of interaction effect study between CSR and RI it cannot be argued that the mean values of dependent variables are significantly different (stat. $F=0.2966 ; p=$ 0.9145 ). Since there are statistically significant differences between the average market value of the RESPECT Index companies and the others, as the next step the econometric model was applied to test the relationship between the market value and the RI variable (1 - company in the RESPECT Index; 0-otherwise). As control variables the employment size and the variable indicating the affiliation to the PLWIG-BANKI index were used (1 - company in PL-WIG-BANKI; 0 - otherwise). The obtained model is shown in Table 5.

Table 5. Linear regression analysis for market value as depend variable

\begin{tabular}{lll}
\hline Dependent variable: $($ market value) & & Coefficients \\
\hline & $5228.723 * * * *$ & $\mathbf{3 0 2 6 . 7 9} * * * *$ \\
Independent variable: $\mathrm{RI}_{\mathrm{t}-1}$ & -222.736 & -59.83 \\
Intercept & $2026.756 * * *$ & $-2697.59 * * * *$ \\
Control variables: & $1.48606 * * * *$ & \\
$\quad$ PL-WIG-BANK index (0-1) & -208.691 & 27.27 \\
$\quad$ Number of employees & & $1.90 * * * *$ \\
$\quad$ Dept/total assets & $514.88^{* * * *}$ & $879.03 * * * *$ \\
$\quad$ Book value & 0.896 & 0.9319 \\
Stat. $\mathrm{F}=$ &
\end{tabular}

Using standard test we observe that the relationship between all independent variables in the model and the market value is statistically significant. Similarly, the fit of the model is high $(\mathrm{R} 2=89.6 \%)$, the random component is not heteroscedastic Thus, the relationship between market value and RI can be indicated.

The second research hypothesis concerned the impact of the financial result on the company's probability to publish a CSR report and the impact of the financial result on the probability of the incorporation of the company to the Respect Index. In order to verify the hypothesis, logit models were constructed separately for the CSR report publication and RI variables. The results of the analysis are presented in Tables 6-9.

In each of the estimated models, the ROA and ROE values of the previous year were used as the financial result. At the same time, it was also verified whether the fact of being quoted within the PL-WIG-BANKI index of the largest banks quoted on the Warsaw Stock Exchange, influences the probability of the CSR report being 
The relation between the CSR and the accounting information system data in Central and Eastern European (CEE) countries - the evidence of the Polish financial institutions

published by the company and whether it increases the likelihood of incorporation into the RESPECT Index.

Table 6. Logit regression analysis using CSR ( 1 - publication of the report; 0 otherwise) as depend variable and financial data from previous year as independent variables

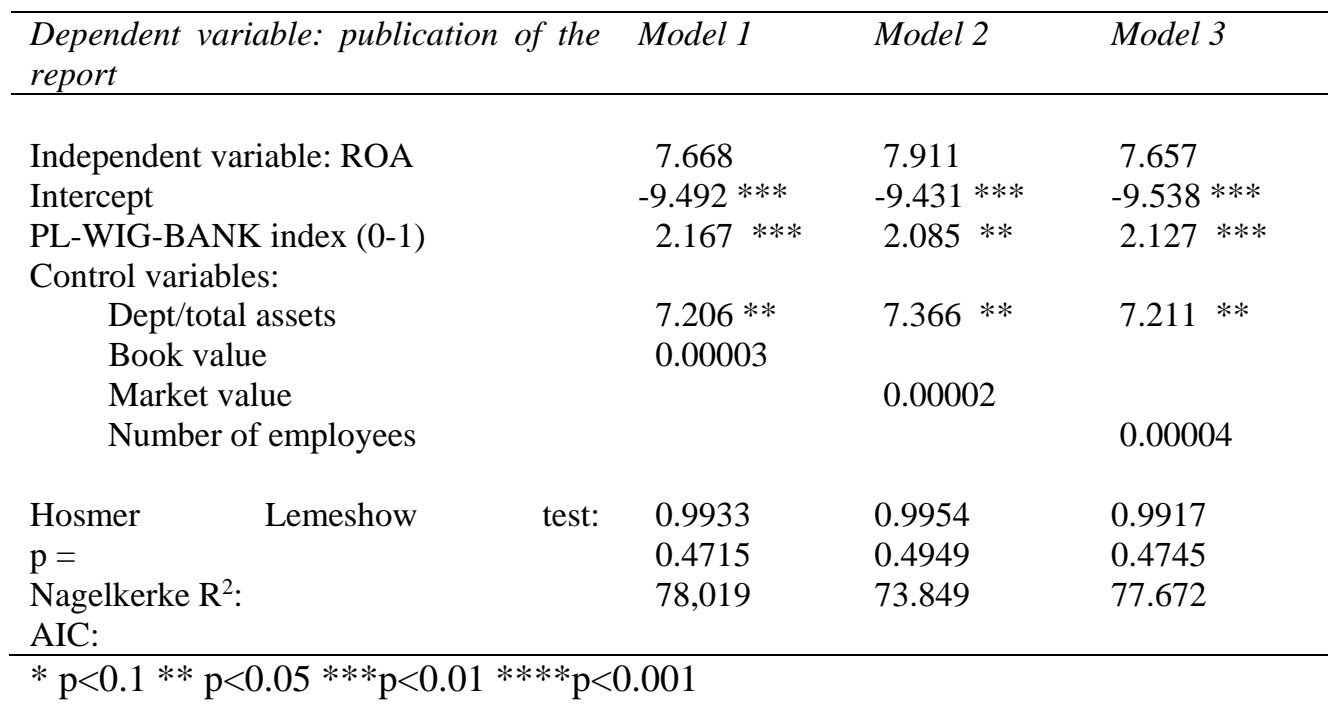

Table 7. Logit regression analysis using CSR (1 - publication of the report; 0 - otherwise) as depend variable and financial data from previous year as independent variables

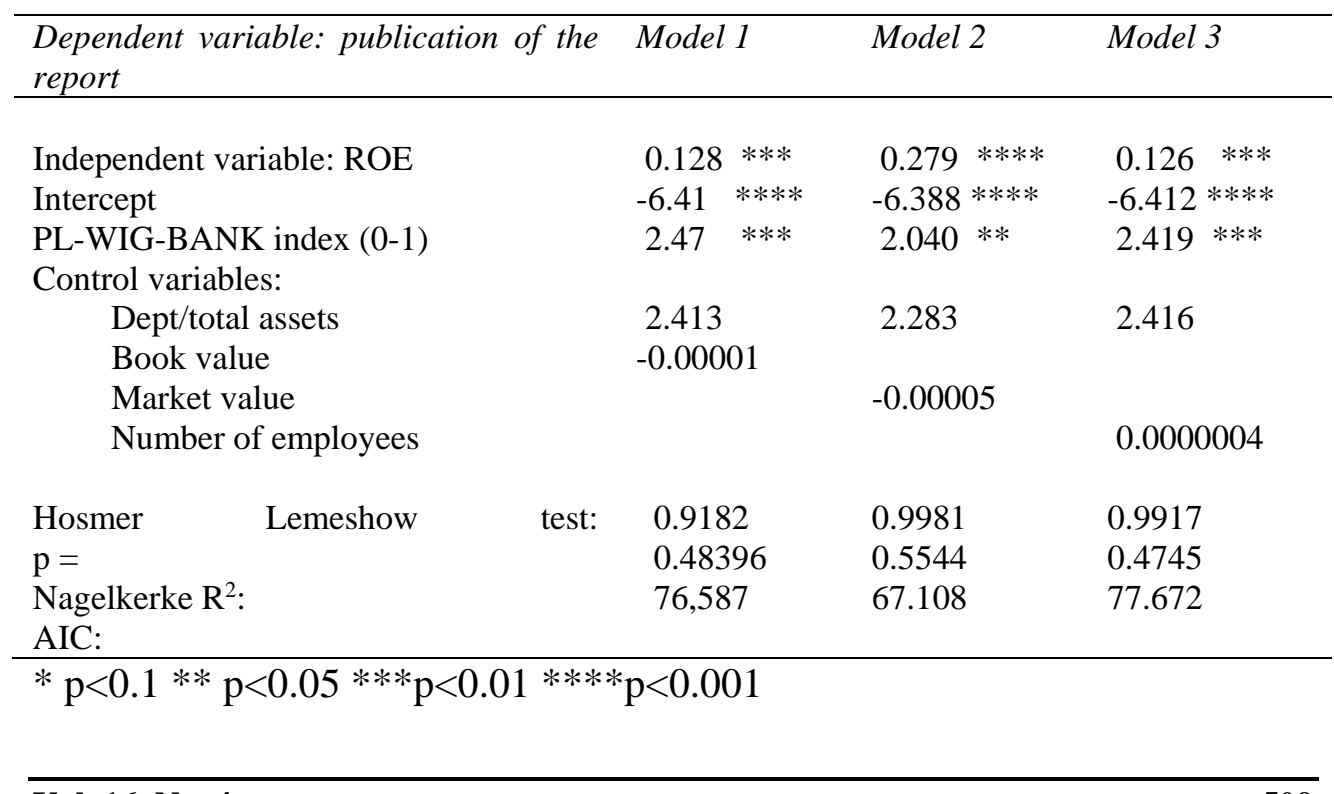


Table 8. Logit regression analysis using RI (1 - company in Respect Index; 0 - otherwise) as depend variable and financial data (ROA) from previous year as independent variables

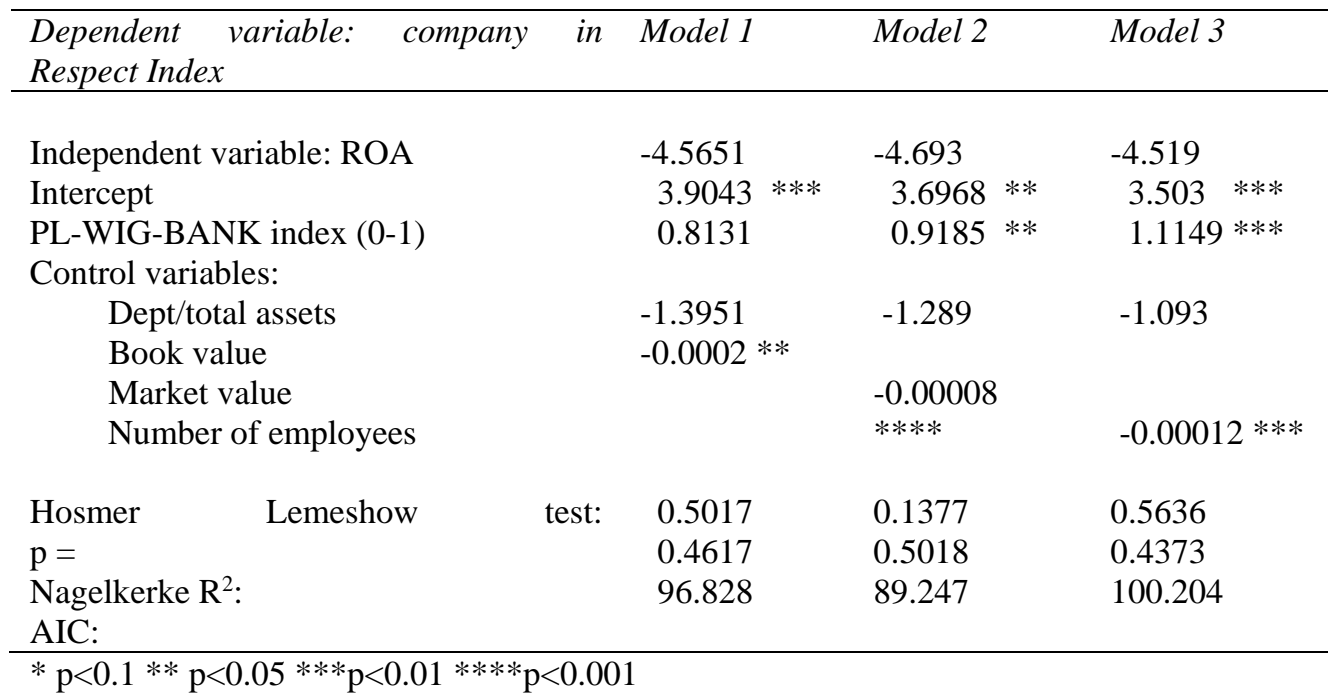

Table 9. Logit regression analysis using RI (1 - company in Respect Index; 0 - otherwise) as depend variable and financial data (ROE) from previous year as independent variables

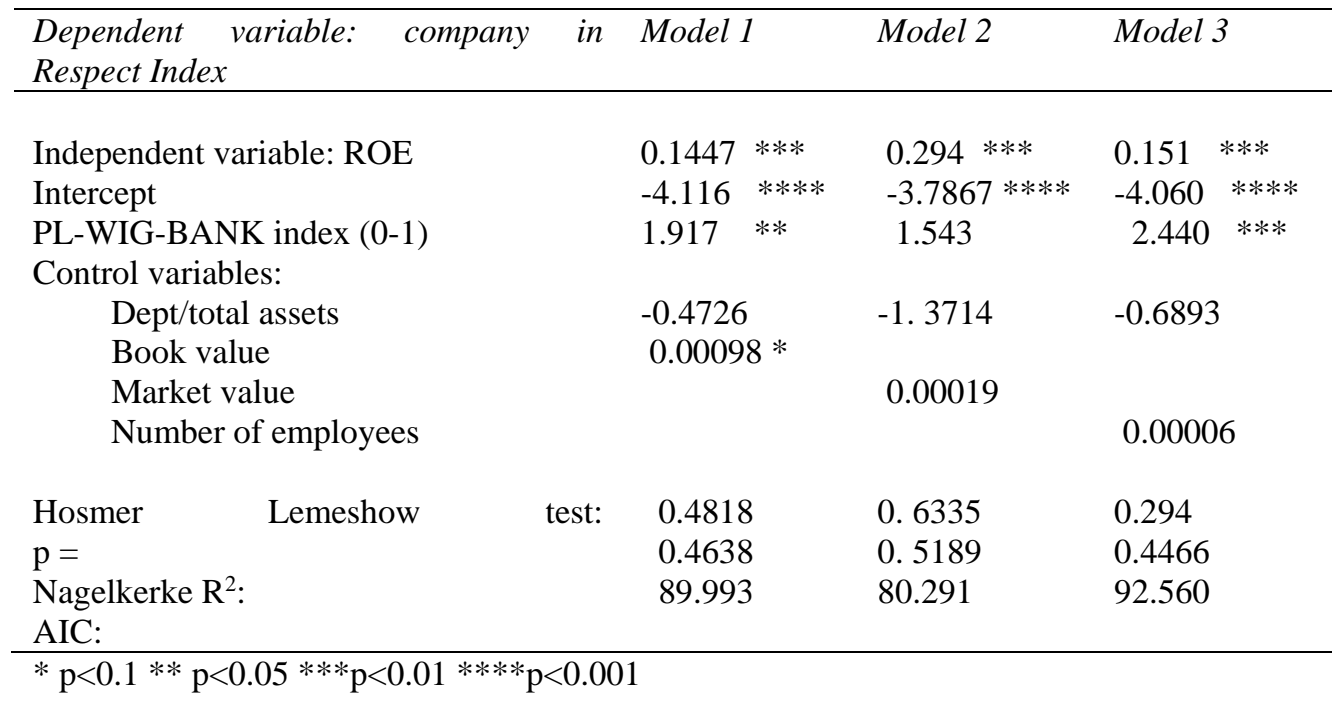


In all estimated models, it appears that the ROA value has no statistically significant impact either on the likelihood of a CSR report being published or on the likelihood of incorporation into the RESPECT Index (see Table 6 and Table 9).

Models in which the independent variable is ROA tend to generally model the probability of a dependent variable in a proper way. However, this is the result of other variables. In turn, the models in which the ROE is taken an independent variable have a significant effect on the probability of the dependent variable. The higher the ROE value, the greater the likelihood that the company will decide to publish a CSR report or that it will be included in the RESPECT Index the following year. In almost all models, the company's PL-WIG-BANK index participation has a significant impact on the probability of a dependent variable.

Apart from one case (Table 8, Model 1), this is the most important factor increasing the likelihood of a CSR report being published and increasing the probability of inclusion in the RESTECT Index. In all analyzed cases, the best results were obtained for Model 2, where the control variables are the debt ratio and the market value of the company. They have the lowest Akaike (1974) information criterion (AIC), and the highest $\mathrm{R}^{2}$. Also based on the HosmerLemeshow (2013) test there is no reason to reject the hypothesis that the observed and predicted values are equal.

\section{Conclusions}

CSR-related matters in CEECs has become "an important concept materializing in the accounting academic and practitioner literature, as well as in the practices of local companies" (Albu et all: 193). The 2008 financial crisis brought social responsibility to the important issues agenda in many financial institutions all over the world, including the CEE region. Applying more responsible attitude to the business running and communicating on that was treated as the way of reestablishing credibility and regaining legitimacy by financial sector.

The study presents the conducted analysis of the link between being socially responsible and achieving tangible financial outcomes in CEECs, on the example of Poland. The study attempted also to check if having financial sources influences the involvement in the socially responsible actions and reporting on that. The statistical results of the paper reveal that the publication of a CSR report has not influence the changes in the company's financial results; correlation coefficients have not shown that there is such a link. This results fall in line with the results obtained by Stouhal et al. (2015) that empirically proved no relationship between the disclosure of standalone CSR reports and financial performance in two other 
countries of CEE e.g. Czech and Estonia. On contrary to their study, our research showed a relatively weak relationship in case of a change in market value. The results of this analysis demonstrate also that the fact of publishing CSR report did not reveal significant differences in the financial performance compared to companies that do not publish this kind of report. This result falls in line with Djalilov and Hölscher (2016: 6), stating "where the business environment is not well-developed, markets do not reward banks engaged in social and environmental activities".

A similar analysis was carried out in the group of companies that were included in the RESPECT Index and the rest of companies. In case of companies listed in the RESPECT Index the results demonstrated however, that there is a clear correlation between the fact that the company is listed on that index and the market value. This means that companies included in that index tend to have higher market value. Also the average market value of companies in RESPECT Index is different from the average market value of other companies. We assume however that this may be caused also by the specific high requests concerning the inclusion of companies into this index that appeals not only to CSR engagement but also to the responsibility concerning financial measures themselves therefore the companies that are admitted into the index they already have a sound financial situation.

An econometric model presented in the paper was developed to explain the relationship between the RESPECT Index and the market value in the following year. In this model as the explanatory (independent) variable, apart from Respect Index variable ( 1 in the RESPECT Index; 0 - otherwise) the size of employment and the participation in the PL-WIG-BANKI index (embracing the largest listed banks in Warsaw) were taken into account. There was a statistically significant relationship between the market value and the three variables tested. These empirical results give grounds for rejecting the first research hypothesis. In the same way the social impact and the trade-off hypothesis are denied.

This is a clear sign that the market and the public is reluctant in considering the CSR importance of financial institutions. The results obtained from the first part of research highlight that the CSR activities do not impact the bottom line of the financial institutions or at least that the effects are not seen in the following year. It may be assumed that or CSR efforts are not focused properly, or they are not communicated effectively. We assume also that the factor of time is important, we may expect that the reaction of the public on the CSR activities, especially in case of the loss of trust, may be delayed. In this study one-year time-lag was applied. Maybe the public needs more time to recognize the CSR involvement that would contribute to the improvement of financial performance of socially responsible institutions. To rebuilt trust and credibility it takes time. One should also consider that the Polish financial market is still quite young therefore we may assume that the institutional factors and the development stage of this market influences the 
The relation between the CSR and the accounting information system data

in Central and Eastern European (CEE) countries - the evidence

of the Polish financial institutions

reaction of the public on the CSR initiatives and the degree to which CSR reports publications/ being listed on the Respect Index contributes to the financial bottom line.

In order to verify the second research hypothesis, the probability logit models were constructed, testing the probability of CSR report publishing and the probability of incorporating the company into the RESPECT Index depending on the financial result obtained in the preceding year. It has been shown that ROE is an important independent variable for both the likelihood of publication of the CSR report for the following year as well as for the probability of inclusion in the RESPECT Index. Similarly, the statistically significantly higher probability for the dependent variable was obtained with the variable informing about affiliation to the PL-WIGBANKI index. On the other hand, ROA does not significantly influence the probability of a dependent variable. This is a result other than that obtained at work (Waddock \& Graves, 1997), where the significant independent variable was ROA. We may therefore conclude that there is a will of companies from the financial sector to get involved in the CSR activities (and communicate on them) when the financial resources permit it. The involvement is surely related to the expectations of its positive results. This falls in line with the study of Kundid and Rogošić (2011) carried out the empirical research on all banks in Croatia and statistically confirmed that large and more profitable banks disclose more CSR activities. The results obtain in our study are however contrary to those achieved by Djalilov (2015) concerning mainly transition countries, where he found that banks with a lower level of profitability are more interested to engage in social projects. He also proved that CSR activities would improve the financial performance of the banks of the transition countries.

Contrary, our study proves that in Poland the awareness of positive impact of CSR is higher in the institutions that are willing to engage in the CSR than of the market and public that stills fails to react on the CSR efforts of financial institutions in the way it would translate into measurable results for the companies. We may deduct that there is a significant difference between CEE countries and other transitional countries. The result of this study fall in line with observations of Grigore and Candidatu (2009: 84) that while analysing the perception of CSR in Romania and Bulgaria state: "there is room for improvement in the perception of corporate social responsibility area, but good social and environmental practices are in place and they constitute the basis for further development of corporate social responsibility practices". The results obtained confirm also the observations of Elms (2006: 206) concerning the stakeholders' lack of activism in CEE and the low reaction on CSR. Elms indicated that "if stakeholders' value responsibility, corporations will too". Although more than 10 years passed since that study, still in Poland the clients do not value the CSR engagement. 
The present study is subject to certain limitations. Firstly, the sample size is relatively small, however it covers all the public companies in the financial sector in Poland in 2012-2015. Secondly, the time frame of the research is fairly short (i.e. 4 years). Thirdly, the study ignores control variables like age of firm, growth of firm, capital intensity, leverage, risk, R\&D intensity, industry type, etc. that may have significant influence on this relationship. Several control variables that were considered during data collection included the capital structure (including whether the company is part of an international financial corporation), the type of financial activity (banks, insurance companies, investment firms) or the fact that CSR report submitted to external audit. Due to incomplete data in the database or in some cases due to heterogeneous information contained in the databases used, these explanatory variables are also excluded. Another restriction concerns a variable that informs the CSR report as a variable informing about the applicable social responsibility policy. We do not have information on the standards that published CSR reports meet.

Therefore, the results of study should be interpreted in light of these limitations. The directions of future research could be an attempt to overcome those limitations. The cross-national comparison could also be valuable to better understand the specifics of the Polish financial market and CSR in the international context, especially in the CEE region. Future research could also focus on the analysis of the CSR activity on the CFP in much longer lag period, the reconstructed credibility and trust, if ever, may occur after many years and as a result of a very focused engagement in CSR supported by its effective communication.

\section{Acknowledgement}

The paper was presented during the conference International Conference Accounting and Management Information Systems (AMIS 2017). The paper was completed with the feedback received from conference participants, and also with the valuable comments from article`s reviewers.

\section{References}

ACCA (2013) What do investors expect from non-financial information?, http://www.accaglobal.com/content/dam/acca/global/PDFtechnical/sustainability-reporting/tech-tp-wdir.pdf (access: 08.01.2017). 
The relation between the CSR and the accounting information system data in Central and Eastern European (CEE) countries - the evidence of the Polish financial institutions

Aggarwal, P. (2013) "Impact of sustainability performance of company on its financial performance: a study of listed Indian companies", Global Journal of Management and Business Research, vol. 13, no. 11: 60-70

Akaike, H. (1974) "A new look at the statistical model identification", IEEE Transactions on Automatic Control, vol. 19 (6): 716-723

Albertini, E. (2012) "Does environmental strategy improve financial performance? a meta-analytical review", Academy of Management Conference, Boston USA.

Albu, C. N., Balsari, Ç \& Krasodomska, J. (2016) "Introduction to the Special Issue on Corporate Social Reporting in Central and Eastern Europe", Accounting and Management Information Systems, vol. 15, no. 2: 193-205

Allouche, J. \& Laroche, P. (2005) "A meta-analytical investigation of the relationship between corporate social and financial performance", Revue de Gestion des Ressources Humaines, vol. 57 (1): 8-41

Asatryan, R. \& Březinová, O. (2014) "Corporate Social Responsibility and Financial Performance in the Airline Industry in Central and Eastern Europe", Acta Universitatis Agriculturae et Silviculturae Mendelianae Brunensis, vol. 62: 633-639

Barjaktarović, 1., Paunović, M. \& Ječmenica, D., (2013) "Development of the banking sector in cee countries - comparative analysis", Journal of Central Banking Theory and Practice, vol. 2: 93-114

Beck, T. (2006) Creating an Efficient Financial System: Challenges in a Global Economy, World Bank Policy Research paper WPS 3856

Belfo, F. \& Trigo A. (2013) "Accounting information systems: tradition and future directions", Procedia Technology, vol. 9: 534-546

Bossone, B. (2000) "What makes banks special? a study of banking, finance, and economic development", World Bank Policy Research Working Papers, no. 2408 .

Caroll, A.B., (1991) "The pyramid of corporate social responsibility: Toward the moral management of organizational stakeholders", Business Horizons, vol. 34, Iss 4, July-August: 39-48.

Centrum CSR, Mielechow, P. \& Piskalski, G. (2009) "CSR and Polish Business on Foreign Markets. Preliminary research report", Friedrich Ebert Foundation Warsaw Office 2009.

Clark, G. L., Feiner, A. \& Viehs, M. (2015) "From the Stockholder to the Stakeholder: How Sustainability Can Drive Financial Outperformance", doi:10.2139/ssrn.2508281.

Cornett, M. Erhemjamts, O. \& Tehranian, H. (2014) "Corporate social responsibility and the impact on financial performance: Investigation of U.S. commercial banks", Boston college, from https://www2.bc.edu/hassantehranian/CSR-Performance\%20Relationship\%20for\%20Banks\%20Jan\% 202014.pdf 
Cowton, C. J. (2002) "Integrity, responsibility and affinity: three aspects of ethics in banking", Business Ethics: A European Review, vol. 11 (4): 393-400

Csafor, H., (2008) "Corporate social responsibility in Central and Eastern Europe", in M. Carmona, J. Szlavik and E. Zam., (Eds.) "Perdiodica Oeconomica Regional Development and Competitiveness", pp. 115-126

Daniel, F, Lohrkeb, F. T., Fornaciari Ch. J. \& Turner R. A. (2004) "Slack resources and firm performance: a meta-analysis", Journal of Business Research, vol. 57: $565-574$

Decker, S. \& Sale, C. (2009) "An Analysis of Corporate Social Responsibility, Trust and Reputation in the Banking Profession", in: S.O. Idowu, W.L., Filho (Eds.) Professionals perspectives if corporate social responsibility, Springer-Verlag, Berlin-Heidelberg.

Djalilov, K., Vasylieva, T., Lyonov, S. \& Lasukova, A., (2015) "Corporate Social Responsibility and Bank Performance in Transition Countries", Corporate Ownership and Control, January: 1-25

Djalilov, K. \& Hölscher, J. (2016) "Antecedents of corporate social responsibility in the banks of Central-Eastern Europe and in the countries of the former Soviet union", BAFES - Bournemouth Accounting, Finance \& Economic Series, NO 05: 1-26

Dyczkowska, J., Krasodomska, J. \& Waniak, J., (2016) "CSR in Poland Institutional context, legal framework and voluntary initiatives", Accounting and Management Information Systems, vol. 15, No. 2: 206-254

Elms, H., (2006) "Corporate (and stakeholder) responsibility in Central and Eastern Europe", International Journal of Emerging Markets, vol. 1(3): 203-211

Ernst \& Young (2009) "Non-financial reporting", Retrieved Feb. 28, 2016, from http://www.ey.com/Publication/vwLUAssets/Nonfinancial_reporting/\$FILE /Climate\%20change_Non\%20financial\%20reporting.pdf

Feltham, S. (2016) "A Snapshot of CSR in Central and Eastern Europe", http://www.triplepundit.com/2016/10/snapshot-csr-central-eastern-europe/

Fijałkowska, J. (2012),,Społeczna odpowiedzialność wyzwaniem dla rachunkowości" [Corporate Social Responsibility as a Challenge for Accounting], Przedsiębiorczość i Zarządzanie, vol. 13(1): 141-154

Fijałkowska, J. \& Zyznarska-Dworczak, B. (2017) "Społeczna odpowiedzialność biznesu a tworzenie wartości banków" [Corporate Social Responsibility and Value Creation of Banks], The Journal of Management and Finance (forthcoming).

Filatotchev, I., Buck, T., \& Zhukov, V. (2000) "Downsizing in privatized firms in Russia, Ukraine, and Belarus", Academy of Management Journal, vol. 43(3): 286-304

Furceri, D. \& Zdziencka, A. (2010) "Banking crisis and short and medium term output loses in developing countries: The role of structural and policy variables, MPRA", working paper 22078, Retrieved from http://mpra.ub.unimuenchen.de/22078/2/Banking_Crises_and_Short_and_M edium_Term_Output_Losses_in_Developing_Countries_MRPA.pdff 
The relation between the CSR and the accounting information system data in Central and Eastern European (CEE) countries - the evidence of the Polish financial institutions

Furrer, O., C. P. Egri, D. A. Ralston, W. Danis, E. Reynaud, I. Naoumova, M. Molteni, A. Starkus, F. L. Darder, M. Dabic, \& Furrer-Perrinjaquet, A., (2010) "Attitudes toward corporate responsibilities in Western Europe and in Central and East Europe", Management International Review, vol. 50(3): 379-398

Friedman, M. (1970) "The social responsibility of business is to increase its profits", New York Times Magazine, September 13.

Gaultier-Galliard, S., \& Louisot, J-P., (2006) "Risks to Reputation: A Global Approach", The Geneva Papers, vol. 31: 425-445

Gray, R., Owen, D. \& Maunders, K. (1987) Corporate Social Reporting, PrenticeHall, Englewood Cliffs, NJ.

Griffin, J.J. \& Mahon, J.F. (1997) "The Corporate Social Performance and Corporate Financial Performance Debate: Twenty-Five Years of Incomparable Research", Business and Society, vol. 36(1): 5-31

Grigore, L.N. \& Candidatu, C., (2009) "The Perception and Role Of Corporate Social Responsibility In Central And Eastern Europe", Romanian Economics and Business Review, vol. 4(4): 79-88

Hernaus, A. I. \& Stojanovic, A. (2015) "Determinants of bank social responsibility: case of Croatia", Ekonomie a Management, vol. 18(2): 117-134

Hirigoyen, G. \& Poulain-Rehm, T. (2015) "Relationships between corporate social responsibility and financial performance: What is the causality"?, Journal of Business and Management, vol. 4 (1): 18-43.

Hosmer, D. W., \& Lemeshow, S. (2013) Applied Logistic Regression, New York: Wiley

Huang, XB \& Watson L (2015) "Corporate social responsibility research in accounting", Journal of Accounting Literature, vol. 34(1): 1-16

Inglehart, R. \& Welzel, C. (2005) Modernization, cultural change, and democracy: The human development sequence, New York: Cambridge University Press.

International Business Leaders Forum (IBLF) (2003) IBLF Members. http://www.iblf.org/csr/csrwebassist.nsf/content/g1.html, (access: 23.05.2015).

International Monetary Fund (2016) Regional Economic Issues Central, Eastern, and Southeastern Europe How to Get Back on the Fast Track, International Monetary Fund, May 16, https://www.imf.org/external/pubs/ft/reo/2016/ eur/eng/pdf/rei0516.pdf, (access: 31.07.2017).

Ioannou, I. \& Serafeim, G. (2010) "What Drives Corporate Social Performance?: International Evidence from Social, Environmental and Governance Sources", Harvard Business School.

ISO 26000 (2010) Guidance Standard on Social Responsibility, International Organization for Standardization's, http://www.cnis.gov.cn/wzgg/201405/ P020140512224950899020.pdf, (access: 23.05.2015). 
Kemmelmeier, M., Krol, G. \& Kim, Y. H. (2002) "Values, economic, and proenvironmental attitudes in 22 societies", Cross-Cultural Research, vol. 26(3): 256-285

Kleine, J., Krautbauer M. \& Weller T. (2013) "Nachhaltige Investments aus dem Blick der Wissenschaft: Leistungsversprechen und Realität", Research Center for Financial Services Steinbeis- Hochschule, Berlin.

Koleva, P., Rodet-Kroichvili, N., David, P. \& Marasova, J. (2010) "Is corporate social responsibility the privilege of developed market economies? Some evidence from Central and Eastern Europe", The International Journal of Human Resource Management, vol. 21(2): 274-293

Kundid, A. \& Rogošić, A. (2011) "Bank Online Reporting: Comparative Advantage, Formalism of Fashion?", Global Business \& Economics Anthology, vol. 2(2): 500-518

Levine, R. (1997) "Financial development and economic growth: views and agenda", Journal of Economic Literature, vol. 35: 688-726.

Levine, R. (2005) "Finance and growth: theory and evidence", in: Aghion, P \& Durlauf, S. (eds.), Handbook of economic growth, Elsevier Science, The Netherlands.

Lewicka-Strzalecka, A. (2006) "Opportunities and limitations of CSR in the postcommunist countries: Polish case", Corporate Governance, vol. 6(4): 440-448

Llewellyn, D. (2005) "Trust and confidence in financial services: a strategic challenge", Journal of Financial Regulation and Compliance, vol. 13(4): 333-346.

Lopez, M. V., Garcia, A., \& Rodriguez, L. (2007) „Sustainable development and corporate performance: A study based on the Dow Jones Sustainability Index", Journal of Business Ethics, vol. 75(3): 285-300

Margolis, J. D., Elfenbein H. \& Walsh J.P. (2007) "Does it pay to be good? A meta-analysis and redirection of research on the relationship between corporate social and financial performance", Working Paper, Ross School of Business - University of Michigan.

Margolis, J. D. \& Walsh, J. P. (2001) "People and profits?: The search for a link between a company's social and financial performance", Mahwah, N.J: Lawrence Erlbaum Associates.

Marquez A., \& Fombrun, C.J. (2005) "Measuring Corporate Social Responsibility", Corporate Reputation Review, vol. 7 (4): 304-308

McGuire, J. B., A. Sundgren, \& T. Schneeweiss (1988) "Corporate Social Responsibility and Firm Financial Performance", Academy of Management Journal, vol. 31 (4): 854-872

McWilliams A. \& Siegel D. (2001) "Corporate social responsibility: A theory of the firm perspective", Academy of Management Review, vol. 26 (1): $117-127$

Merton, R.C. (1995) "A functional perspective of financial intermediation", Financial Management, vol. 24(2): 23-41 
The relation between the CSR and the accounting information system data in Central and Eastern European (CEE) countries - the evidence of the Polish financial institutions

Minor, D.B. (2009) Corporate Social Responsibility as Reputation Insurance: Theory and Evidence, Haas School of Business, UC Berkeley.

Mikołajewicz G. \& Nowicki J. (2016) „Tworzenie wartości przedsiębiorstwa z uwzględnieniem aspektów środowiskowych i społecznych" [Creation of company value, with environmental and social aspects], in: Kochalski, C., Zielony controlling $i$ finanse. Podstawy teoretyczne [Greening and finance. Theoretical Foundations], Wydawnictwo C.H.Beck, Warszawa, pp. $75-104$

Moon, J. (2007) "The Contribution of Corporate Social Responsibility to Sustainable Development", Sustainable Development, vol. 15: 296-306

Nagelkerke, N.J.D. (1991) "A note on a general definition of the coefficient of determination", Biometrika, vol. 78: 691-692

Novokmet, A.K. \& Rogošić, A. (2016) "Bank Sustainability Reporting within the GRI-G4 Framework", Zeszyty Teoretyczne Rachunkowości, vol. 88, no. 144: $109-123$

Olsen, R. (2008) "Trust as risk and the foundation of investment value", Journal of Socio Economics, no. 37(4): 2189-2200

Olson M. W. (2006) "Are Banks Still Special?", Annual Washington Conference of the Institute of International Bankers, Washington, D.C., BIS Review, no. 20.

Orlitzky, M., Schmidt, F. L. \& Rynes, S. L. (2003) "Corporate social and financial performance: A meta-analysis", Organization Studies, vol. 24 (3): 403-441

Peloza, J. (2009) "The challenge of measuring financial impacts from investments in corporate social performance", Journal of Management, vol. 35 (6): $1518-1541$

Preston L.E. \& O’Bannon D.P. (1997) “The corporate social-financial performance relationship: a typology and analysis", Business and Society, no. 36: 419429

Rogošić A., Čaljkušić A. (2015) "Disclosure of the socially responsible activities of the banks in Croatia and Slovenia", Proceedings of the 3rd International OFEL Conference on Governance, Management and Entrepreneurship The Quest for Organizational Identity, D. Tipurić, M. Daraboš (eds), Dubrovnik, Croatia, 17-18 April 2015, CIRU - Governance Research and Development Centre, pp. 313-324.

Rossier, J., (2003) "Ethics and Money: What is required of the banking professional", La Lettre, Geneva Private Bankers Association, no. 23, March.

Schanz, K. (2006) "Reputation and reputational risk management", The Geneva Papers on Risk and Insurance, vol. 31: 377-381

Scholtens B. (2009) "Corporate social responsibility in the international banking industry", Journal of Business Ethics, no. 86: 159-175 
Seifert, B., Morris S.A. \& Bartkus B.R. (2004) "Having, giving, and getting: Slack resources, corporate philanthropy, and firm financial performance", Business \& Society, vol. 43(2): 135-161

Smith, N. C. (2002) "Arguments for and against corporate social responsibility", In: L. P. Hartman (Ed.), Perspectives in business ethics, New York: The McGraw-Hill Companies: 231-236.

Stansfield, G. (2006) "Some Thoughts on Reputation and Challenges for Global Financial Institutions", The Geneva Papers, no. 31: 470-479

Steurer, R. \& Konrad, A. (2009) "Business-society relations in Central-Eastern and Western Europe: How those who lead in sustainability reporting bridge the gap in corporate (social) responsibility", Scandinavian Journal of Management, vol. 25: 23-36

Steurer, R. \& Martinuzzi, A. (2012) "Public Policies on CSR in Europe: Themes, Instruments, and Regional Differences", Corporate Social Responsibility and Environmental Management, no. July: 206-227

Strandberg, C. (2005) "Best practices in sustainable finance", Standberg Consulting, from http://www.corostrandberg.com/pdfs/Sustainable\% 20Finance\%20\%20Best\%20Practices.pdf.

Strouhal, J., Gurvits, N., Nikitina-Kalamae, M \& Startseva, E. (2015) "Finding the Link between CSR Reporting and Corporate Financial Performance: Evidence on Czech and Estonian Listed Companies", Central European Business Review, vol. 4 (3): 48-59

UNDP (2007) Baseline study on CSR practices in the New EU Member States and Candidate

Countries, http://www.acceleratingcsr.eu/uploads/docs/BASELINE_STUDY_ON.pdf.

UNEP (2004) "Finance and Stability in Central \&Eastern Europe", http://www.unepfi.org/fileadmin/documents/ceetf_finance_sustainability_20 04_01.pdf

Vaughan-Whitehead, D. C. (2003) EU enlargement versus social Europe? The uncertain future of the European model, Cheltenham: Edward Elgar.

Vynoslavska, O., McKinney, J. A., Moore, C. W. \& Longenecker, J. G. (2005) "Transition ethics: a comparison of Ukrainian and United States business professionals", Journal of Business Ethics, vol. 61(3): 283-299

Waddock, S. A. \& Graves, S. B. (1997) "The corporate social performancefinancial performance link", Strategic Management Journal, vol. 303-319

Wang Q., Dou J. \& Jia S. (2016) "A meta-analytic review of corporate social responsibility and corporate financial performance. The moderating effect of contextual factors", Business \& Society, vol. 55 issue 8: 1083-1121.

World Economic Forum (2012) "The role of financial services in society a multistakeholder compact", from http://www3.weforum.org/docs/ WEF_FS_RoleFinancialServicesSociety_Report_2013.pdf (20.03.2017).

Yilmaz, B., Yilmaz, O. \& Akmese, H. (2016) "The role of accounting information system in business in terms of corporate governance and social responsibility of accounting in crisis periods and a research", RSEP International Conferences on Social Issues and Economic Studies 
The relation between the CSR and the accounting information system data in Central and Eastern European (CEE) countries - the evidence of the Polish financial institutions

Zyznarska-Dworczak, B. (2016) "Determinanty rozwoju sprawozdawczości niefinansowej w świetle pozytywnej i normatywnej teorii rachunkowości" [The Development of Non-Financial Reporting in the Light of Positive and Normative Accounting Theories], Prace Naukowe Uniwersytetu Ekonomicznego (AE) we Wroctawiu, no. 436: 307-315

Živković, S. \& Aktan, B. (2009) "Global financial crisis and VaR performance in emerging markets: A case of EU candidate states - Turkey and Croatia", The Proceedings of Rijeka Faulty of Economics- Journal of Economics and Business, vol. 27 (1): 149-170

${ }^{\mathrm{i}}$ According to the classification of the International Monetary Fund (2016), the following countries are included in Central East Europe: Albania, Belarus, Bosnia and Herzegovina, Bulgaria, Croatia, Czech Republic, Estonia, Hungary, Kosovo, Latvia, Lithuania, Macedonia, Moldova, Montenegro, Poland, Romania, Russia, Serbia, Slovak Republic, Slovenia, Turkey, and Ukraine. 